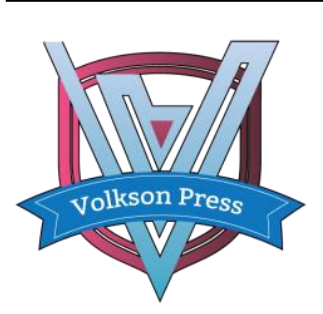

ISBN: 978-1-948012-12-6

\title{
ELECTROCHROMIC PROPERTIES OF MULTILAYER FILM BASED ON POLYOXOMETALATE AND CDS NANOPARTICLES
}

\author{
Jia-Ning Tan, Ning Yang, Ru-Fan Han, Su-Yang Feng, Yan-Yan Yang*, Xiao-shu Qu, Hui Feng \\ Jilin Institute of Chemical Technology,45 Chengde Street, 132073, JiLin, China \\ *Corresponding Author Email: yyy200409@163.com
}

This is an open access article distributed under the Creative Commons Attribution License, which permits unrestricted use, distribution, and reproduction in any medium, provided the original work is properly cited.

\section{ARTICLE DETAILS}

\section{Article History:}

Received 26 June 2018

Accepted 2 July 2018

Available online 1 August 2018

\section{ABSTRACT}

The electrochromic films of PEI/[ $\left.\mathrm{P}_{5} \mathrm{~W}_{30} / \mathrm{PEI}\right]_{20}$ and $\mathrm{PEI} /\left[\mathrm{P}_{5} \mathrm{~W}_{30} / \mathrm{CdS}\right]_{20}$ were composed of the polyethyleneimine (PEI), polyoxometalate cluster $\mathrm{K}_{12.5} \mathrm{Na}_{1.5}\left[\mathrm{NaP}_{5} \mathrm{~W}_{30} \mathrm{O}_{110}\right] \cdot 15 \mathrm{H}_{2} \mathrm{O}\left(\mathrm{P}_{5} \mathrm{~W}_{30}\right)$ and cadmium sulfide (CdS) nanoparticles. They were fabricated on fluorine-doped tin oxide (FTO) glass and quartz by the layer-by-layer self-assembly method, respectively. The composition and growth process of the two films were characterized by ultraviolet-visible spectra. The electrochemical properties of the films were investigated by cyclic voltammetry and a double-potential step chronoamperometric experiment. The PEI/ $\left[\mathrm{P}_{5} \mathrm{~W}_{30} / \mathrm{CdS}\right]_{20}$ film reveals higher electrochromic performance than the $\mathrm{PEI} /\left[\mathrm{P}_{5} \mathrm{~W}_{30} / \mathrm{PEI}\right]_{20}$ film, whose optical contrast is up to $51.04 \%$, increase by $68.12 \%$, and shows the response time for coloration $2.58 \mathrm{~s}$ (bleaching $1.96 \mathrm{~s}$ ). Furthermore, the $\mathrm{PEI} /\left[\mathrm{P}_{5} \mathrm{~W}_{30} / \mathrm{CdS}\right]_{20}$ film has a coloration efficiency of $127.18 \mathrm{~cm}^{2} / \mathrm{C}$, improve of $133.92 \%$. Obviously, the electrochromic performance of composite film has been enhanced by the addition of CdS nanoparticles.

\section{KEYWORDS}

Electrochromic, Polyoxometalate, layer-by-layer self-assembly, CdS nanoparticles.

\section{INTRODUCTION}

Electrochromic materials (ECMs) can achieve reversible changes from colorless to colored with small applied potentials [1,2]. They are being developed for applications in smart window, anti-glare rearview mirrors, safety helmets, military camouflage equipment and so on [3-6]. ECMs could be classified into two types: inorganic ECMs and organic ECMs. The inorganic ECMs exhibit various advantages of optical contrast, high thermal stability, long durability, multi-method of processing $[7,8]$.

Polyoxometalates (POMs) represent a well-known class of metal oxide nanoclusters with their particularly interesting structures and electrical properties, they have been applied in many areas such as medicine, catalysis and materials science [9-12]. One of the most important properties of POMs is that they can undergo rapid, reversible and stepwise multielectron-transfer reactions without changing their structures. The POMs could also be decorated or designed rationally to be obtain certain functions. Therefore, the POMs-based electrochromic (EC) films have fast response, good stability, and low-cost, which makes them become an important part of promising inorganic ECMs $[13,14]$. The $\left[\mathrm{P}_{5} \mathrm{~W}_{30} \mathrm{O}_{110}\right]^{15-}\left(\mathrm{P}_{5} \mathrm{~W}_{30}\right)$ is an excellent candidate for the POMs-based EC films, with high negative charge, wide $\mathrm{pH}$ stability range, reversible redox properties.

The method of layer-by-layer (LbL) self-assembly has been widely used to fabricate multilayer films, and relied on alternately electrostatic adsorption of oppositely charged species $[15,16]$. Recent years, there were several groups have been devoted their efforts to the investigation of POMs-based EC films using the LbL method. And a number of EC materials based on $\mathrm{P}_{5} \mathrm{~W}_{30}$ have been reported, which exhibited high optical contrast, fast response time and reversible photo/electrochromic properties [17-20].

Cadmium sulfide (CdS) nanoparticles is a versatile semiconductor possessing a tunable $2.4-4.2 \mathrm{eV}$ bandgap [21]. The electrochromic performance of the POMs-based film would improve with the CdS nanoparticles based on quantum size effect and multiple excitation electron generation effect [22,23]. In this paper, the EC film of $\mathrm{PEI} /\left[\mathrm{P}_{5} \mathrm{~W}_{30} / \mathrm{PEI}\right]_{20}$ and $\mathrm{PEI} /\left[\mathrm{P}_{5} \mathrm{~W}_{30} / \mathrm{CdS}\right]_{20}$ composed of PEI, $\mathrm{P}_{5} \mathrm{~W}_{30}$ and $\mathrm{CdS}$ nanoparticles were fabricated on fluorine-doped tin oxide (FTO) glass and quartz by LbL method, respectively. The results indicate that electrochromic response efficiency and reversibility of POMs-baesd film was enhanced by the CdS nanoparticles.

\section{EXPERIMENTAL}

\subsection{Materials}

$\mathrm{K}_{12.5} \mathrm{Na}_{1.5}\left[\mathrm{NaP}_{5} \mathrm{~W}_{30} \mathrm{O}_{110}\right] \cdot 15 \mathrm{H}_{2} \mathrm{O}\left(\mathrm{P}_{5} \mathrm{~W}_{30}\right)$ and $\mathrm{CdS}$ nanoparticles were prepared according to literature method and identified by ultravioletvisible (UV-vis) spectra, respectively [24,25]. FTO glass (Nippon Sheet Class) was purchased from Heptachroma (Dalian, China). Quartz was purchased from Hongjun optical instrument operation department (Jiangsu, China). Polyethelenimine (PEI) was purchased from Sigma Aldrich and used without further treatment. Other reagents were of AR grade. The water used in all experiments was deionized.

\subsection{Preparation of the multilayer film}

FTO glass and quartz substrates were used for preparation of the multilayer films. First, the surface of the FTO glass and quartz were cleaned according to our previous procedure, respectively, dipped into $5 \times 10^{-3} \mathrm{M}$ PEI solution (containing $1 \mathrm{M} \mathrm{NaCl} \mathrm{pH}=4.0$ ) for 12 hours, and followed by washing with deionized water [26]. Then the substratesupported precursor films were alternately dipped into $\mathrm{P}_{5} \mathrm{~W}_{30}\left(1 \times 10^{-3} \mathrm{M}\right)$ for $7 \mathrm{~min}$ and PEI solutions for $4 \mathrm{~min}$, rinsed with deionized water after each dipping. This process was repeated until the desired number of $\mathrm{PEI} /\left[\mathrm{P}_{5} \mathrm{~W}_{30} / \mathrm{PEI}\right]$ layers was obtained. Preparation process of the $\mathrm{PEI} /\left[\mathrm{P}_{5} \mathrm{~W}_{30} / \mathrm{CdS}\right]$ film is same as $\mathrm{PEI} /\left[\mathrm{P}_{5} \mathrm{~W}_{30} / \mathrm{PEI}\right]$ film, the difference is alternately immersed in $\mathrm{P}_{5} \mathrm{~W}_{30}$ solution and $\mathrm{CdS}$ solution. All procedures were performed at room temperature $\left(25^{\circ} \mathrm{C}\right)$. 


\subsection{Fimes characterization}

Electrochemical experiments were performed on a CHI-660D electrochemistry station (Shanghai CH Instrument Corporation, China). A conventional three electrodes system was used, with the FTO-coated by the self-assembled film as the working electrode, $\mathrm{Ag} / \mathrm{AgCl}(3 \mathrm{M} \mathrm{KCl})$ as the reference electrode and a Pt wire as counter electrode. $0.2 \mathrm{M} \mathrm{Na}_{2} \mathrm{HPO}_{4}$ $\mathrm{NaH}_{2} \mathrm{PO}_{4}(\mathrm{pH}=6.5)$ buffer solution is used as an electrolyte. Visible light absorption spectra of the films were obtained on a TU-1901 UV-vis spectra. Spectroelectrochemical measurements of the composite films were performed by combining in UV-vis spectra with electrochemical analysis.

\section{RESULTS AND DISCUSSION}

\subsection{UV - vis absorption spectra}

UV-vis spectroscopy was used to monitor the layer-by-layer assembling process of $\mathrm{PEI} /\left[\mathrm{P}_{5} \mathrm{~W}_{30} / \mathrm{PEI}\right]_{20}$ and $\mathrm{PEI} /\left[\mathrm{P}_{5} \mathrm{~W}_{30} / \mathrm{CdS}\right]_{20}$ films, owing to its facility and usefulness in evaluating the growth process of the layers. As shown in Figure 1, the two films exhibit absorption (Abs) peaks at 202 and $281 \mathrm{~nm}$ in the UV region, which belong to the ultraviolet characteristic absorption peak of $\mathrm{P}_{5} \mathrm{~W}_{30}$, and show that the $\mathrm{P}_{5} \mathrm{~W}_{30}$ without any structural alteration and the assembly process of the composite film is uniform and stable. The inset of Figure 1 (a) and (b) display the plots of the absorbance values for the two films at $202 \mathrm{~nm}$ and $281 \mathrm{~nm}$ which increase linearly with the number of layers. Since the absorption peak of CdS is weak, the films growth curve was not obvious at $375 \mathrm{~nm}$. However, in the same layer, the $\mathrm{PEI} /\left[\mathrm{P}_{5} \mathrm{~W}_{30} / \mathrm{CdS}\right]_{20}$ film has a higher Abs values, indicating that the CdS nanoparticles successfully incorporated into the film.
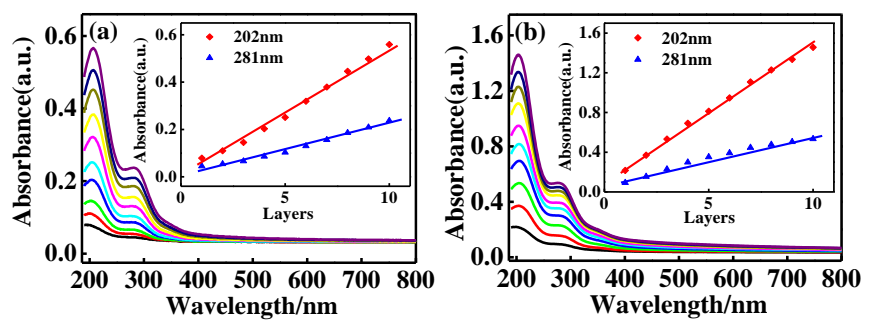

Figure 1: (a) UV-vis absorption spectra of PEI/[P $\left.\mathrm{P}_{5} \mathrm{~W}_{30} / \mathrm{PEI}\right]_{20}$ and (b) $\mathrm{PEI} /\left[\mathrm{P}_{5} \mathrm{~W}_{30} / \mathrm{CdS}\right]_{20}$ films with $\mathrm{n}=1-10$ on quartz substrate. Inset: the absorbance at 202 and $281 \mathrm{~nm}$ as a function of number of layers

\subsection{Electrochemistry}

Figure 2 gives the $\mathrm{CV}$ curves of $\mathrm{PEI} /\left[\mathrm{P}_{5} \mathrm{~W}_{30} / \mathrm{PEI}\right]_{20}$ and $\mathrm{PEI} /\left[\mathrm{P}_{5} \mathrm{~W}_{30} / \mathrm{CdS}\right]_{20}$ films at a scan rate of $50 \mathrm{mV} / \mathrm{s}$. It is seen that the four oxidation peaks of $\mathrm{PEI} /\left[\mathrm{P}_{5} \mathrm{~W}_{30} / \mathrm{PEI}\right]_{20}$ film appear at $-0.85,-0.72,-0.46$ and $-0.13 \mathrm{~V}$, and the reduction peaks center at $-0.93,-0.80,-0.60$ and $-0.16 \mathrm{~V}$. For $\mathrm{PEI} /\left[\mathrm{P}_{5} \mathrm{~W}_{30} / \mathrm{CdS}\right]_{20}$ film, the four oxidation peaks are located at -0.83 , $0.70,-0.43$ and $-0.12 \mathrm{~V}$, whereas the four peaks appear at $-0.95,-0.83$, 0.63 and $-0.20 \mathrm{~V}$. The reduction peak potentials of PEI/[ $\left.\mathrm{P}_{5} \mathrm{~W}_{30} / \mathrm{CdS}\right]_{20}$ film are lower than the PEI/[ $\left.\mathrm{P}_{5} \mathrm{~W}_{30} / \mathrm{PEI}\right]_{20}$, but the oxidation peak potentials, peak current density, and area currents are all higher than that of $\mathrm{PEI} /\left[\mathrm{P}_{5} \mathrm{~W}_{30} / \mathrm{PEI}\right]_{20}$ film. Therefore, the electrochemical activities were improved by the CdS nanoparticles has been successfully incorporated into the composites.

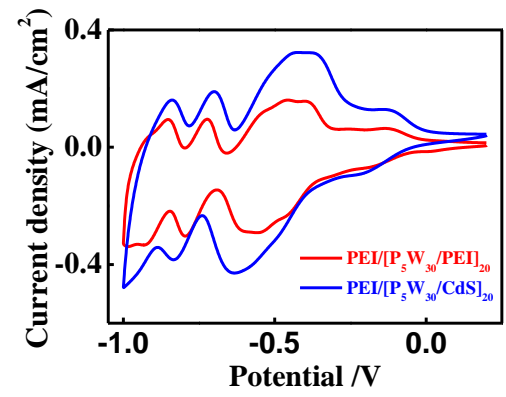

Figure 2: $\mathrm{CV}$ curves of $\mathrm{PEI} /\left[\mathrm{P}_{5} \mathrm{~W}_{30} / \mathrm{PEI}\right]_{20}$ and $\mathrm{PEI} /\left[\mathrm{P}_{5} \mathrm{~W}_{30} / \mathrm{CdS}\right]_{20}$ films in $0.2 \mathrm{M} \mathrm{Na}_{2} \mathrm{HPO}_{4} / \mathrm{NaH}_{2} \mathrm{PO}_{4}(\mathrm{pH}=6.5)$ buffer solution at a scan rate of $50 \mathrm{mV} / \mathrm{s}$
The electrochromic properties of $\mathrm{PEI} /\left[\mathrm{P}_{5} \mathrm{~W}_{30} / \mathrm{PEI}\right]_{20}$ and $\mathrm{PEI} /\left[\mathrm{P}_{5} \mathrm{~W}_{30} / \mathrm{CdS}\right]_{20}$ films are studied by measuring the optical absorbance in the visible region under various potentials. From Figure 3 (a) and (b), the Abs values of the two films increases gradually, and the corresponding extrinsic color transitions from colorless to blue with the decreasing potential. Under the same applied potential, the PEI/ $\left[\mathrm{P}_{5} \mathrm{~W}_{30} / \mathrm{CdS}\right]_{20}$ film has a higher Abs. It indicates that the successfully incorporating of $\mathrm{CdS}$ nanoparticles has improved the EC property of multilayer film. When an oxidation potential of $1.0 \mathrm{~V}$ was applied, the absorption peak of the film in the visible region disappeared, and it returned to colorless. The composite film has a reversible electrochromism.
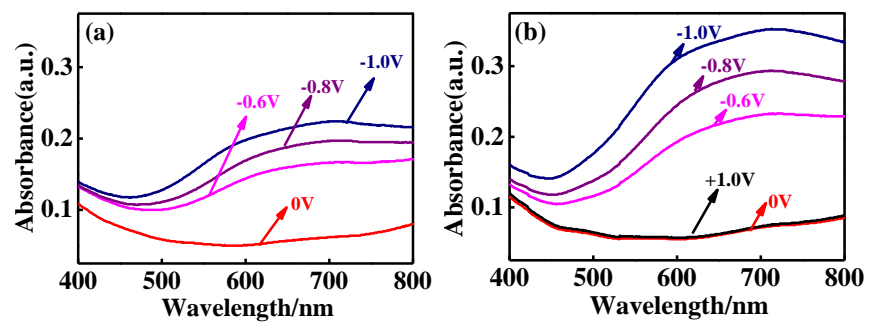

Figure 3: (a) UV-vis absorption spectra of PEI/[ $\left.\mathrm{P}_{5} \mathrm{~W}_{30} / \mathrm{PEI}\right]_{20}$ and (b) $\mathrm{PEI} /\left[\mathrm{P}_{5} \mathrm{~W}_{30} / \mathrm{CdS}\right]_{20}$ films under applied different potentials

To evaluate the performance of the two films, a double-potential step ($1.0 \mathrm{~V}$ and $+1.0 \mathrm{~V}$ ) chronoamperometric experiment was conducted at 650 $\mathrm{nm}$. As shown in Figure 4, the optical contrast of the PEI/[P $\left.\mathrm{P}_{5} \mathrm{~W}_{30} / \mathrm{CdS}\right]_{20}$ film is $51.04 \%$, which is higher than the PEI/[ $\left.\mathrm{P}_{5} \mathrm{~W}_{30} / \mathrm{PEI}\right]_{20}$ film (30.36\%).
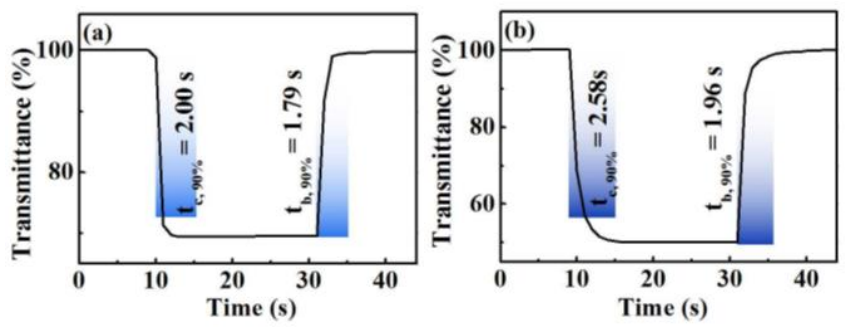

Figure 4: Coloration and bleaching time extracted for a $90 \%$ transmittance change for the PEI/[P $\left.\mathrm{P}_{5} \mathrm{~W}_{30} / \mathrm{PEI}\right]_{20}(\mathrm{a})$, and $\mathrm{PEI} /\left[\mathrm{P}_{5} \mathrm{~W}_{30} / \mathrm{CdS}\right]_{20}$ (b) EC flims at $650 \mathrm{~nm}$

The coloration time $\left(t_{c}, 90 \%\right)$ or bleaching time $\left(t_{b}, 90 \%\right)$ extracted for a $90 \%$ transmittance change was an important criterion for judging an electrochromic film [27]. The PEI/[ $\left.\mathrm{P}_{5} \mathrm{~W}_{30} / \mathrm{CdS}\right]_{20} \mathrm{EC}$ film were detected to be $2.58 \mathrm{~s}\left(\mathrm{t}_{\mathrm{c}}, 90 \%\right)$ and $1.96 \mathrm{~s}\left(\mathrm{t}_{\mathrm{b}, 90 \%}\right)$, whose coloration time were longer than the PEI/[P $\left.\mathrm{P}_{5} \mathrm{~W}_{30} / \mathrm{PEI}\right]_{20} \mathrm{EC}$ film with $\mathrm{t}_{\mathrm{c}, 90 \%}=2.00 \mathrm{~s}$ and $\mathrm{t}_{\mathrm{b}, 90 \%}=1.79 \mathrm{~s}$. Which may be due to after CdS incorporated into the PEI/[ $\left.\mathrm{P}_{5} \mathrm{~W}_{30} / \mathrm{CdS}\right]_{20}$ film, the thickness of the film and the amount of substances involved in the reaction are increased. The beaching time of the both films are less than coloration time, and the response time of the two films are all within 3 seconds. It indicates that adding of CdS nanoparticles can improve the optical contrast of the composite film.

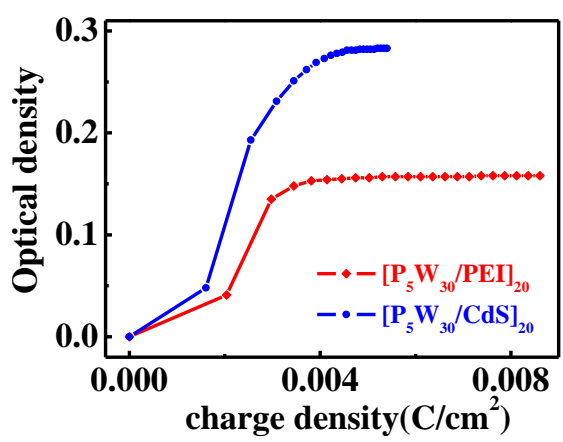

Figure 5: Plot of optical density versus charge density for the $\mathrm{PEI} /\left[\mathrm{P}_{5} \mathrm{~W}_{30} / \mathrm{PEI}\right]_{20}$ and $\mathrm{PEI} /\left[\mathrm{P}_{5} \mathrm{~W}_{30} / \mathrm{CdS}\right]_{20} \mathrm{EC}$ films

At the same time, the coloration efficiency (CE) is also a crucial parameter to judge an EC film [28]. The comparison of the CE of two types of EC films 
is illustrated in Figure 5. The calculated CE values are 127.18 and 54.37 $\mathrm{cm}^{2} / \mathrm{C}$. The higher CE value indicated that the PEI/[ $\left.\mathrm{P}_{5} \mathrm{~W}_{30} / \mathrm{CdS}\right]_{20} \mathrm{EC}$ film exhibited a large optical modulation with a small charge introduced or extracted. Obviously, the addition of $\mathrm{CdS}$ nanoparticles can improve the electrochromic activity of the composite film.

\section{CONCLUSIONS}

The mutilayer films of PEI/[P $\left.\mathrm{PW}_{30} / \mathrm{PEI}\right]_{20}$ and $\mathrm{PEI} /\left[\mathrm{P}_{5} \mathrm{~W}_{30} / \mathrm{CdS}\right]_{20}$ had been successfully prepared by LbL method. The PEI/ $\left[\mathrm{P}_{5} \mathrm{~W}_{30} / \mathrm{CdS}\right]_{20}$ film exhibits well electrochromic with reversibility, high optical contrast and suitable response time. The optical contrast of the $\mathrm{PEI} /\left[\mathrm{P}_{5} \mathrm{~W}_{30} / \mathrm{CdS}\right]_{20}$ film is up to $51.04 \%$, higher than the $\mathrm{PEI} /\left[\mathrm{P}_{5} \mathrm{~W}_{30} / \mathrm{PEI}\right]_{20}$ film (30.36\%), and the response time for coloration and bleaching is $2.58 \mathrm{~s}$ and $1.96 \mathrm{~s}$, respectively. The two films display reversible electrochromic behavior from colorless to blue over the potential range from $-1.0 \mathrm{~V}$ to $+1.0 \mathrm{~V}$. The corresponding extrinsic color of the $\mathrm{PEI} /\left[\mathrm{P}_{5} \mathrm{~W}_{30} / \mathrm{CdS}\right]_{20}$ film would become deeper than $\mathrm{PEI} /\left[\mathrm{P}_{5} \mathrm{~W}_{30} / \mathrm{PEI}\right]_{20}$ film by the same negative applied potential. Furthermore, the $\mathrm{CE}$ values of the $\mathrm{PEI} /\left[\mathrm{P}_{5} \mathrm{~W}_{30} / \mathrm{CdS}\right]_{20}$ and $\mathrm{PEI} /\left[\mathrm{P}_{5} \mathrm{~W}_{30} / \mathrm{PEI}\right]_{20}$ are 127.18 and $54.37 \mathrm{~cm}^{2} / \mathrm{C}$. Obviously, the electrochromic performance of composite film has enhanced by the addition of CdS nanoparticles.

\section{ACKNOWLEDGMENTS}

This work was supported by the National Natural Science Foundation of China (No. 1605056), Natural Science Foundation of Jilin Province (No. 20180101292JC and 20180101191JC), the Education Department of Jilin Province (No. JJKH20180548KJ), Jilin Science and Technology Bureau (No. 201750215), Jilin Institute of Chemical Technology (No. 2015001).

\section{REFERENCES}

[1] Jensen, J., Hosel, M., Dyer, A.L., Krebs, F.C. 2015. Advanced Function Materials, 25 (14), 2073-2090. doi: 10.1002/adfm.201403765

[2] Liu, S.P., Xu, L., Gao, G.G., Xu, B.B. 2009. Thin Solid Films, 517 (16), 4668-4672. doi: 10.1016/j.tsf.2009.02.125

[3] Shankar, S., Lahav, M., Boom, M.E.V.D. 2015. Journal of the American Chemical Society, 137 (12), 4050-4053. doi: 10.1021/jacs.5b02864

[4] Dyer, A.L., Bulloch, R.H., Zhou, Y.H., Kippelen, B., Rwynolds, J.R., Zhang, F.L. 2014. Advanced Materials, 26 (28), 4895-4900. doi 10.1002/adma.201401400

[5] Runnerstrom, E.L., Llordes, A., Lounis, S.D., Milliron, D.J. 2014. Chemical Communications, 50 (73), 10555-10572. doi: $10.1039 / \mathrm{c} 4 \mathrm{cc} 03109 \mathrm{a}$

[6] Sonmez, G. 2005. Chemical Communications, 42 (42), 5251-5259. doi: $10.1039 / \mathrm{b} 510230 \mathrm{~h}$

[7] Palilis, L.C., Vasilopoulou, M., Douvas, A.M., Georgiadou, D.G., Kennou, S., Stathopoulos, N.A., Constantoudis, V., Argitis, P. 2013. Solar Energy Materials \& Solar Cells, 114 (7), 205-213. doi: 10.1016/j.solmat.2013.02.034

[8] Ma, D.Y., Shi, G.Y., Wang, H.Z., Zhang, Q.H., Li, Y.G. 2012. Journal of Materials Chemistry A, 1 (3), 684-691. doi: 10.1039/C2TA00090C

[9] Avendaño, E., Berggren, L., Niklasson, G.A., Granqvist, C.G., Azens, A. 2006. Thin Solid Films, 496 (1), 30-36. doi: 10.1016/j.tsf.2005.08.183

[10] Qu, X.S., Liu, S.P., Yang, Y.Y. 2015. Journal of Northeast Normal University (Natural Science), $32 \quad$ (1), 28-33. doi: 10.13563/j.cnki.jmolsci.2016.01.003

[11] Zhu, W., Zhang, W.J., Li, S., Ma, H.Y., Chen, W., Pang, H.J. 2013. Sensors and Actuators B Chemical, 181 (5), 773-781. doi: dx.doi.org/10.1016/j.snb.2013.01.050

[12] Zhang, D., Tu, J.P., Xiang, J.Y., Qiao, Y.Q., Xia, X.H., Wang, X.L., Gu, C.D. 2011. Electrochimica Acta, 56 (27), 9980-9985. doi: 10.1016/j.electacta.2011.08.119

[13] Yamase, T. 1998. Chemical Reviews, 98 (1), 307-326. doi: $10.1021 /$ cr9604043

[14] Gao, G.G., Xu, L., Wang, W.J., Wang, Z.Q., Qiu, Y.F., Wang, E.B. 2005. Electrochimica Acta, 50 (5), 1101-1106. doi: 10.1016/j.electacta.2004.08.006

[15] Jiang, M., Wang, E.B., Xu, L., Kang, Z.H., Lian, S.Y. 2004. Journal of Solid State Chemistry, 177 (4), 1776-1779. doi: 10.1016/j.jssc.2003.12.039

[16] Qu, X.S., Liu, S.P., Yang, Y.Y. 2015. Journal of Northeast Normal University (Natural Science), 47 (3), 100-104. doi: 10.16163/j.cnki.22$1123 /$ n.2015.04.020

[17] Liu, S.Q., Kurth, D.G., Möhwald, H., Volkmer, D. 2002. Advanced

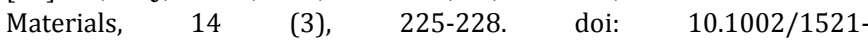
4095(20020205)14:33.0.CO; 2-F

[18] Liu, S.Q., Möhwald, H., Volkmer, D., Kurth, D.G. 2006. Langmuir, 22 (5), 1949-1951. doi: 10.1021/la0523863

[19] Zhang, T.R., Liu, S.Q., Kurth, D.G., Faul, C.F.J. 2009. Advanced Function Materials, 19 (4), 642-652. doi: 10.1002/adfm.200801409

[20] Yang, Y.Y., Tian, B.Y., Feng, S.Y., Qu, X.S. 2017. Journal of Northeast Normal University (Natural Science Edition), 2 (49), 101-104. doi: 10.16163/j.cnki.22-1123/n.2017.02.019

[21] Hodos, M., Horváth, E., Haspel, H., Kukovecz, A., Kónya, Z., Kiricsi, I. 2004. Chemical Physics Letters, 399 (4), 512-515. doi: 10.1016/j.cplett.2004.10.064

[22] Chen, S.G., Paulose, M., Ruan, C.M., Mor, G.K., Varghese, O.K., Kouzoudis, D., Grimes, C.A. 2006. Journal of Photochemistry \& $\begin{array}{lllll}\text { Photobiology A Chemistry, } 177 & \text { (2), 177-184. doi: }\end{array}$ 10.1016/j.jphotochem.2005.05.023

[23] Peter, L.M., Riley, D.J., Tull, E.J., Wijayantha, K.G.U. 2002. Chemical Communications, 10 (10), 1030-1031. doi: 10.1039/B201661C

[24] Wang, B., Wang, X.H., Li, J.M., Wang, X.H., Xie, L.J., Duan, L.M., Liu, Z.R. 2017. Chinese Journal of Applied Chemistry, 34 (2), 233-241. doi: 10.11944/j.issn.1000-0518.2017.02.160125

[25] Rayevska, O.E., Grodzyuk, G.Y., Dzhagan, V.M., Stroyuk, O.L., Kuchmiy, S.Y., Plyusnin, V.F., Crivin, V.P., Valakh, M.Y. 2010. Journal of Physical Chemistry C, 114 (51), 22478-22486. doi: 10.1021/jp108561u

[26] O'Regan, B., Moser, J., Anderson, M. 1990. Journal of Physical Chemistry, 94 (24), 8720-8726. doi: 10.1021/j100387a017

[27] Li, K.R., Zhang, Q.H., Wang, H.Z., Li, Y.G. 2016. Journal of Materials Chemistry C, 4 (24), 5849-5857. doi: 10.1039/C6TC01516F

[28] Xie, Z., Gao, L., Liang, B., Wang, X.F., Chen, G., Liu, Z., Chao, J.F., Chen, D., Shen, G.Z. 2012. Journal of Materials Chemistry, 22 (37), 19904-19910. doi: 10.1039/C2JM33622G 